\title{
Metastatic Carcinomas of the Adrenal Glands: From Diagnosis to Treatment
}

\author{
ELEFTHERIOS SPARTALIS ${ }^{1}$, IOANNIS DRIKOS ${ }^{1}$, ARGYRIOS IOANNIDIS ${ }^{1}$, DIMOSTHENIS CHRYSIKOS ${ }^{2}$, \\ DIMITRIOS I. ATHANASIADIS ${ }^{3}$, MICHAEL SPARTALIS ${ }^{1}$ and DIMITRIOS AVGERINOS ${ }^{4}$ \\ ${ }^{1}$ Laboratory of Experimental Surgery and Surgical Research N.S. Christeas, Medical School, \\ National and Kapodistrian University of Athens, Athens, Greece; \\ ${ }^{2}$ University Department of Surgery, General and Oncologic Hospital of Kifissia 'Agii Anargiri', Athens, Greece; \\ ${ }^{3} 1$ st Department of Surgery, 'Papageorgiou' General Hospital, Medical School, \\ Aristotle University of Thessaloniki, Thessaloniki, Greece; \\ ${ }^{4}$ Department of Cardiothoracic Surgery, New York Presbyterian and Weill Cornell Medicine, New York, NY, U.S.A.
}

\begin{abstract}
Background/Aim: Adrenal glands are one of the most common sites of cancer metastasis. The treatment options include either surgery or chemotherapy and/or radiotherapy while certain diagnosis is made via percutaneous biopsy or fine needle aspiration (FNA), guided by CT scan. This review aimed to present the current practice regarding the diagnosis and treatment of adrenal cancer metastasis. Materials and Methods: A PRISMA-compliant systematic search of the PubMed, Cochrane, EMBASE, AMED, CINAHL, WoS, BIOSIS, LILACS, ASSIA, SCEH, SCIRUS databases, and JIT medical feed sources was performed through November 5th, 2018. Results: A total of 87 original studies including 660 patients with adrenal metastasis were analyzed. Most preferred treatment was excision of the gland in $76.58 \%$ of the cases, while most of adrenal metastases were found at autopsy (43.88\%) followed by computed tomography guided biopsy (33.09\%). Conclusion: Adrenalectomy following metastatic disease to the adrenals should be performed when the lesion is isolated in the gland and the site of primary cancer has or can be resected.
\end{abstract}

The adrenal glands are commonly infiltrated with metastases in patients with a variety of neoplastic diseases; taking into account their weight, adrenal glands are considered the most common site of metastasis (1). Large autopsy studies have shown that the percentage of cancers which give metastases

Correspondence to: Eleftherios D. Spartalis, MD, MSc, Ph.D., FACS, 49 Vasilissis Sofias Ave. Athens, 10676, Greece. Tel: +30 6974714078, e-mail: eleftherios.spartalis@gmail.com

Key Words: Cancer, metastatic, adrenal, diagnosis, treatment, review. to the adrenal glands is about $42 \%$ for lung (2), $58 \%$ for breast (2), 16\% for gastric (3), 10.3\% for esophageal (3), $14 \%$ for colorectal cancer (4) and $50 \%$ for malignant melanomas (2). Metastases to the adrenals have also been reported for renal cell carcinoma (5-15), hepatocellular carcinoma $(16,17)$, carcinoma of the bladder (18), lymphoma (19-21), seminoma of the testis (19) and osteogenic sarcoma (22). In patients who have an adrenal mass and an extra-adrenal malignancy, the frequency of this mass being metastatic ranges from $32 \%$ to $73 \%$ (23).

Metastatic carcinomas are in most cases asymptomatic because metastatic lesions fail to destroy enough tissue to produce clinical signs or symptoms of insufficiency (24). In only a few reported cases they caused Addison's disease, (2, $9,18-21,25)$ or hypoaldosteronism (16). They are discovered incidentally during an imaging procedure (incidentalomas), in patients with proven malignant disease (26), and their prevalence ranges from $0.3 \%$ to $5 \%$ in patients having abdominal CT scans (27).

Materials and methods. An exhaustive literature search between 1976 and November 5th of 2018 was performed using PubMed (Medline), Cochrane Library/Cochrane Register of Controlled Trials, EMBASE, AMED (Allied and Complimentary Medicine Database), CINAHL (Cumulative Index to Nursing and Allied Health Literature), ISI Web of Science (WoS), BIOSIS, LILACS (Latin American and Caribbean Health Sciences Literature), ASSIA (Applied Social Sciences Index and Abstracts), SCEH (NHS Evidence Specialist Collection for Ethnicity and Health) and SCIRUS databases. The authors also searched just-in-time (JIT) medical feed sources as returned from Terkko (provided by the National Library of Health Sciences - Terkko at the 
University of Helsinki). The following MESH terms were used in combination with Boolean operators (AND, OR, NOT): "adrenal", "metastasis", "metastatic", "cancer", "carcinoma". Two independent authors (ES, AI) screened all articles retrieved by the initial search as well as the reference lists of the relevant studies. A total of 87 original studies including 660 patients with adrenal metastasis were included.

Diagnosis: Imaging techniques. The most widely preferred and accepted imaging technique for the detection of metastatic adrenal carcinomas is computed tomography (CT). Allard and colleagues have calculated sensitivity and specificity of CT for the detection of metastatic adrenal lesions; a low sensitivity (20.1-41.1\%) and high specificity (99.4\%) were documented (28).

Antonelli et al. have analyzed 1,179 patients treated for renal cancer; of the 914 ipsilateral adrenal glands removed during renal surgery, $854(93.5 \%)$ were normal on pathological examination, $28(3 \%)$ had a benign pathology, six $(0.8 \%)$ were directly infiltrated by the tumour and 26 $(2.7 \%)$ were metastatic. CT had sensitivity, specificity and positive/ negative predictive values of $47 \%, 99 \%, 73 \%$ and $96 \%$, respectively (29).

Porte et al. studied the sensitivity and specificity of CT, MRI and CT plus MRI by examining 443 patients with operable non-small cell lung cancer (NSCLC), 32 of whom had an adrenal mass. The combination of CT and MRI had $80 \%$ specificity and $100 \%$ sensitivity. The imaging features of adrenal metastases were non-specific and size alone was not sufficient for discriminating between metastatic lesions and non-functioning adenomas (30).

In a previous study of ours, the size of an adrenaloma as reported on a CT scan was usually less than the size reported on the histology report. In an analysis of 76 operated patients, we found that the mean estimated diameter of the adrenal tumor was $4.64 \mathrm{~cm}$ on the CT scan and $5.96 \mathrm{~cm}$. in the pathology report (27). It seems that the shape of the adrenal mass found on CT, as well as the homogeneity or heterogeneity of the mass, are poor indicators of metastatic disease $(31,32)$. However, some investigators suggest that the size is the most helpful CT criterion in distinguishing between metastasis and benign masses. Thus, isolated adrenal masses greater than $3 \mathrm{~cm}$ in diameter in patients with known primary cancer, should be viewed with suspicion (31).

Burt et al. have studied the ability of Magnetic Resonance Imaging (MRI) to predict whether an adrenal mass in patients with operable NSCLC is benign or malignant. Twenty-seven patients with a unilateral adrenal mass were entered in the study and the results of MRI diagnosis were compared with those of CT-guided percutaneous needle aspiration. With sensitivity of $100 \%$, specificity of $24 \%$, false-positive rate of $67 \%$ and false-negative rate of $0 \%$, the researchers concluded that even the best currently available
MRI scanning techniques cannot replace biopsy in the evaluation of adrenal masses in patients with lung cancer (33). Goerg and colleagues have used ultrasound for the detection of adrenal masses in patients with bronchogenic carcinoma. An abdominal ultrasound was obtained from 410 patients with lung cancer as part of initial staging and in 44 of them (11\%) an adrenal mass was discovered. Furthermore, ultrasound guided fine-needle biopsy of the adrenal tumors was performed together with sonographic follow-up examinations and 42 adrenal masses (95\%) proved to represent metastases confirmed by progression or regression during sonographic follow-up examinations. The diagnosis of metastatic disease can be given by the change in the size of the adrenal masses under sonographic follow-up examination. It has been suggested that ultrasound guided fine-needle biopsy should only be performed in cases in which prompt diagnosis affects management decision (34). The sonographic characteristics of bilateral adrenal metastases were the subject of the study of Zornoza and Bernardino, who reviewed more than 50 patients with adrenal masses (35). Among them, ten patients were found to have bilateral metastases to the suprarenal glands, which in the transverse plane appeared like the "head light" of a car. This characteristic prompted the investigators to describe the "head light" sign as an accurate sonographic method for diagnosing bilateral adrenal metastases (35).

In addition, Loccoco and colleagues found that a PET-CT scan in the preoperative diagnostic work-up was an independent positive prognostic factor, suggesting the relevance of a proper staging process in oligometastatic NSCLC patients (36).

Quraishi and colleagues have studied 25 patients with lung cancer with iodocholesterol adrenal scans and portrayed iodocholesterol adrenal scanning as a promising technique for the detection of adrenal metastases, but more studies are needed to confirm these results (37). Leitha and associates have reported $100 \%$ sensitivity, $100 \%$ accuracy and $100 \%$ specificity when using ${ }^{123}$ I-Tyr-3-Octreotide for the detection of adrenal metastases in patients with small-cell lung cancer (38).

In recent years, positron emission tomography (PET) has been employed in the diagnosis of metastatic adrenal carcinomas. Studies have confirmed the ability of PET to distinguish malignant from benign tissues (39-41).

Diagnosis: Fine needle aspiration (FNA). Obtaining adrenal tissue has become easier with the advent of CT and ultrasonography, which facilitate accurate needle placement (15). Luciani and colleagues have suggested that the combination of CT, ultrasound and aspiration cytology is useful in the differential diagnosis of secondary (metastatic) from primary adrenal carcinomas (15). Berkman et al. have achieved diagnostic accuracy of $100 \%$ in 15 out of 16 patients with adrenal mass following CT-guided percutaneous 
Spartalis et al: Metastatic Carcinomas of the Adrenal Glands (Review)

Table I. Reported studies on the use of computed tomography (CT) and fine needle aspiration (FNA) in the detection of adrenal metastases.

\begin{tabular}{|c|c|c|c|c|c|c|}
\hline $\begin{array}{l}\text { First } \\
\text { author }\end{array}$ & $\begin{array}{l}\text { Primary } \\
\text { cancer }\end{array}$ & $\begin{array}{l}\text { No. of } \\
\text { patients } \\
\text { examined }\end{array}$ & $\begin{array}{l}\text { No. of patients } \\
\text { with adrenal } \\
\text { mass found }(\%)\end{array}$ & $\begin{array}{l}\text { Masses } \\
\text { detection } \\
\text { technique }\end{array}$ & $\begin{array}{l}\text { No. of patients } \\
\text { with adrenal } \\
\text { metastases }(\%)\end{array}$ & $\begin{array}{l}\text { Technique to } \\
\text { prove } \\
\text { metastases }\end{array}$ \\
\hline Allard (28) & Lung cancer & $\begin{array}{l}91(181 \\
\text { glands) }\end{array}$ & $\begin{array}{l}\text { Depended on } \\
\text { the reader }\end{array}$ & $\mathrm{CT}$ & $\begin{array}{c}32(53 \\
\text { glands) }(35 \%)\end{array}$ & $\begin{array}{l}\text { Histopathologic examination } \\
\text { at autopsy }\end{array}$ \\
\hline Berkman $(42)^{*}$ & & 16 & $16(100 \%)$ & $\mathrm{CT}$ & $4(25 \%)$ & CT-guided biopsy \\
\hline Chapman (46) & $\begin{array}{l}\text { Non-small cell } \\
\text { lung cancer }\end{array}$ & 38 & $5(13 \%)$ & $\mathrm{CT}$ & $5(13 \%)$ & $\begin{array}{l}\text { CT-directed fine needle } \\
\text { aspiration }\end{array}$ \\
\hline Ettinghausen (44) & $\begin{array}{l}\text { Non-small cell } \\
\text { lung cancer }\end{array}$ & 246 & $10(4.1 \%)$ & $\mathrm{CT}$ & $4(1.6 \%)$ & Needle aspiration \\
\hline Harper (47) & $\begin{array}{l}\text { Small cell bronchogenic } \\
\text { cancer }\end{array}$ & 50 & $7(14 \%)$ & Axial CT & $7(14 \%)$ & Postmortem examination \\
\hline Nielsen (48) & $\begin{array}{l}\text { Non-small cell } \\
\text { lung cancer }\end{array}$ & 84 & $15(18 \%)$ & $\mathrm{CT}$ & $4(4.7 \%)$ & $\begin{array}{l}\text { CT-guided percutaneous } \\
\text { needle aspiration }\end{array}$ \\
\hline Oliver (32) & $\begin{array}{l}\text { Non-small cell } \\
\text { lung cancer }\end{array}$ & 330 & $32(9.7 \%)$ & $\mathrm{CT}$ & $8(2.4 \%)$ & $\begin{array}{l}\text { CT-guided biopsy, } \\
\text { Follow-up }\end{array}$ \\
\hline Pagani (43) & $\begin{array}{l}\text { Non-small cell } \\
\text { lung cancer }\end{array}$ & 172 & $20(12 \%)$ & $\mathrm{CT}$ & $19(11 \%)$ & Percutaneous needle biopsy \\
\hline Paivansalo $(49)^{\dagger}$ & & $\begin{array}{l}75(86 \\
\text { glands) }\end{array}$ & $\begin{array}{l}75 \text { (86 } \\
\text { glands) }\end{array}$ & $\mathrm{CT}$ & 38 glands & $\begin{array}{l}\text { Histologically, angiography } \\
\text { and follow-up, U/S or CT } \\
\text { follow-up, course of disease }\end{array}$ \\
\hline Porte (30) & $\begin{array}{l}\text { Non-small cell } \\
\text { lung cancer }\end{array}$ & 443 & $32(7.2 \%)$ & CT, MRI & $18(4 \%)$ & CT-guided biopsy \\
\hline Sandler (31) & Lung cancer & 110 & $11(10 \%)$ & $\mathrm{CT}$ & $11(10 \%)$ & CT-guided biopsy, follow-up \\
\hline Seidenwurm (2) & Various cancers & 21 & $21(100 \%)$ & $\mathrm{CT}$ & 21 & $\begin{array}{c}\text { Gross pathologic postmortem } \\
\text { examination }\end{array}$ \\
\hline Whittlesey (50) & Lung cancer & 185 & $5(2.7 \%)$ & $\mathrm{CT}$ & $6(3 \%)^{\S}$ & $\begin{array}{c}\text { 5-percutaneous biopsy } \\
\text { 1-postmortem examination }\end{array}$ \\
\hline
\end{tabular}

*The authors selected 16 patients with adrenal masses; †The adrenal tumours examined were either primary or metastatic; $¥$ All patients selected had adrenal metastases indicated by gross pathologic postmortem examination; §Adrenal metastases were found in one patient at postmortem examination and not by CT.

aspiration. The authors suggested that CT-guided adrenal biopsy should replace open surgical biopsy for the detection of adrenal metastases because of it is safe and accurate (42).

Pagani has also recommended percutaneous needle biopsy of adrenal masses. Nevertheless, such biopsy should not be preceded, in the case of cancer patients, with normal CT images of the adrenals, because there are complications associated with this technique (43). Porte and associates have claimed that CT-guided biopsy is almost always required for the characterization of an adrenal mass as metastasis, before potentially curative therapy, since it showed $100 \%$ sensitivity and specificity in 443 patients with operable NSCLC, 32 of whom had adrenal an adrenal mass (29). Besides, in the study carried out by Ettinghausen and Burt the cytologic diagnosis of malignancy had also $100 \%$ accuracy (44).

Aspiration cytology under CT or ultrasound guidance can be regarded as the procedure of choice in the diagnostic evaluation of adrenals in patients with malignant neoplasms, as long as the cytologic findings are correlated with the clinical and laboratory data (45). For instance, concerning secondary adrenal carcinomas from small and non-small cell carcinoma of the bronchus, CT guided preoperative evaluation is of paramount importance (46-50). The results of all relevant studies are shown in Table I.

Treatment: Non-surgical treatment. Seven studies $(1,19,51-$ 54) with 122 cases of medically treated secondary adrenal carcinomas are reviewed in Table II. Regarding the site of the primary tumor, the above cases consist of 81 hepatocellular carcinoma (HCC), 25 lung cancers, 14 melanomas, one lymphoma and one unknown.

Yuan and associates have studied 81 cases of HCC and suggested that radiotherapy offers a noninvasive approach with promising local control and acceptable tolerability (54). The median survival period was 15 months. The survival rate at 1 , 2,5 year was $59.9,35.0$, and $12.9 \%$, respectively (54). Branum and colleagues have studied 24 patients with metastatic melanoma, fourteen of whom were treated with chemotherapy for unresectable adrenal tumors at the time of diagnosis. Among these 14 patients, at the time of publication, 11 patients had died with a median survival of 6 months, whereas three remained alive at 8, 37 and 132 months, respectively (1). 
Table II. Review of adrenal metastases non-surgically treated.

\begin{tabular}{|c|c|c|c|c|c|}
\hline First Author & $\mathrm{n}$ & $\begin{array}{l}\text { Age/ } \\
\text { Gender }\end{array}$ & $\begin{array}{l}\text { Primary site } \\
\text { (histologic type) }\end{array}$ & Treatment & Median survival \\
\hline Branum (1) & 14 & $49 *$ & Melanoma & $\begin{array}{c}\text { Chemotherapy (Dacarbazine, } \\
\text { Lomustin, Bleomycin, Vincristine) }\end{array}$ & $\begin{array}{l}3 \text { alive: } \geq 8,37,132 \mathrm{mo} \\
11 \text { dead: } 6 \pm 1 \mathrm{mo}\end{array}$ \\
\hline Carey (19) & 1 & $57 / \mathrm{M}$ & $\begin{array}{l}\text { Malignant lymphoma } \\
\text { (Large cell) }\end{array}$ & $\begin{array}{c}\text { Chemotherapy (Vincristine, Doxorubicin, } \\
\text { Cyclophosphamide, Prednizone) }\end{array}$ & $6 \mathrm{mo}$ \\
\hline Higashiyama (51) & 4 & $54-65 / \mathrm{M}$ & $\begin{array}{l}\text { Lung (3 Adenocarcinoma, } \\
1 \text { Squamous cell) }\end{array}$ & $\begin{array}{l}3 \text { Chemotherapy (Tegafur, Cisplatin, } \\
\text { Vindesine Sulfate), } 1 \text { Radiation }\end{array}$ & $3.5 \mathrm{mo}(2-6 \mathrm{mo})$ \\
\hline Luketich (52) & 6 & $\begin{array}{l}42-75 / 5 \mathrm{M} \\
1 \mathrm{~F}\end{array}$ & $\begin{array}{c}\text { Lung (3 Adenocarcinoma, } \\
2 \text { Squamous cell, } \\
1 \text { Large cell) }\end{array}$ & $\begin{array}{l}\text { Chemotherapy (Mitomycin, } \\
\text { Cis-platinum, Vinblastine) }\end{array}$ & $8.5 \mathrm{mo}$ \\
\hline Soffen (53) & 16 & $47-85^{\dagger}$ & $\begin{array}{l}15 \text { Lung (7 Adenocarcinoma, } \\
3 \text { Squamous cell, } \\
3 \text { Large cell, } 2 \text { Small cell), }\end{array}$ & Radiotherapy & $3.8 \mathrm{mo}(0.5-11 \mathrm{mo})$ \\
\hline Yuan (54) & 81 & $\begin{array}{l}34-82 / 77 \mathrm{M} \\
4 \mathrm{~F}\end{array}$ & $\begin{array}{l}1 \text { Unknown } \\
\text { Hepatocellular }\end{array}$ & $\begin{array}{l}18 \text { patients helical tomotherapy } \\
\text { and } 63 \text { conventional radiotherapy }\end{array}$ & $\begin{array}{c}15 \text { mo }(1,2,5 \text { year } \\
59.9,35.0 \text {, and } \\
12.9 \% \text { respectively })\end{array}$ \\
\hline
\end{tabular}

*Average age. Gender not specified; ${ }^{\dagger}$ Gender not specified. mo: Months.

Soffen and colleagues have studied 16 patients with symptomatic adrenal metastases who received palliative radiotherapy. Fifteen patients had lung cancer as primary malignancy, whereas one had squamous cell carcinoma of unknown primary origin. All patients were treated with radiation for symptomatic disease; median survival was 3.8 months (range $=0.5-11$ months). Based on this outcome, the authors concluded that prognosis for patients receiving palliative radiotherapy for symptomatic adrenal metastases is poor despite high probability of achieving effective palliation (53). In the remaining three studies $(19,51,52)$ low survival has also been reported, suggesting that nonsurgical treatment of adrenal metastases is combined with poor results. The same conclusion can be drawn by three studies $(1,51,52)$ comparing surgical with medical treatment of adrenal metastases.

Treatment: Surgical treatment. A total of 67 cases of secondary adrenal carcinomas surgically treated were identified (Table III). Most cases pertained to lung and renal cancer (55-78).

Surgical treatment - Lung cancer as primary site. In the case of metastasis of lung cancer to the adrenals, surgical intervention is usually avoided, even if the primary cancer is well controlled (i.e. stage T1-2 N0) (79), as distant metastases from lung carcinoma are thought to indicate incurability (75). Nevertheless, a few cases of adrenalectomy for metastatic carcinoma of the lung with good results have been reported $(50,51,64,65,67,69,73,80-85)$. Aggressive approach may prove beneficial for some carefully selected patients, from other primary sites apart from lung und bronchus (86-108).
There have also been reported cases for patients with synchronous and metachronous solitary brain metastases from NSCLC that were treated by surgical removal (109).

Prolonged survival after adrenalectomy was first reported in 1982 by Twomey and colleagues regarding two patients with large cell lung cancer with solitary metastases to the right adrenal gland. The patients remained alive after the resection of the adrenals for fourteen and five years, respectively. This outcome made the authors believe that adrenalectomy should be performed in cases with special features such as good functional status of the patient, aggressive treatment of the primary neoplasm, care to rule out functioning adrenal tumors and the use of CT scans and angiography in order to define the extent of the tumor involvement (55).

Among the 83 cases with isolated adrenal metastases from lung cancer, which were reported in 21 articles $(49,50,55$, $64,65,67,69,71,73-75,78-87)$, fifty-one cases had sufficiently detailed reports to allow safe conclusions (49, $55,64,65,67,69,70,78-80,82-85)$. The remaining 32 cases have been reported in three large-scale studies conducted by two institutions $(51,73,78)$ and in two other smaller case reports $(71,74)$. Among the above 51 patients, synchronous adrenal metastases occurred in 22 patients and metachronous adrenal metastases in 29 patients; 23 were alive at the time of the report with a mean survival of 49 months (range=3168 months), with 5 patients being 5 -year survivors. The remaining 28 patients were dead at the time of the report with a mean survival of 15 months (range=4-36 months). Finally, all the operations conducted were open adrenalectomies apart from four performed by Bendinelli and associates (78), one performed by our team (79), two 
performed by Heniford and colleagues (82), one performed by Tsuji and associates (83), five performed by Valeri and colleagues (85), one performed by Chen and associates (86), and six performed by Kabebew and colleagues (87), which were all laparoscopic.

Taira and colleagues have described a case of surgical treatment by bilateral adrenalectomy of metachronous bilateral adrenal metastases of NSCLC. Three years and six months later, the patient was doing well, with no evidence of recurrence suggesting that selected patients with solitary adrenal metastases of NSCLC can benefit from an aggressive treatment approach, even if such metastases are bilateral (110).

Suzuki and colleagues have reported an attempt of laparoscopic adrenalectomy of an adrenal metastasis from a poorly differentiated adenocarcinoma of the lung, but the procedure had to change to open surgery because of severe adhesions between the adrenal neoplasm and the kidney (71). Yokosuka and colleagues have presented pulmonary adenocarcinoma metastasizing to the adrenal glands, which caused adrenal insufficiency leading to impaired consciousness. After one year under chemotherapy treatment the patient died of disseminated intravascular coagulation due to the tumor (111).

Laparoscopic adrenalectomy has become the gold standard for the treatment of the majority of benign adrenal masses; regarding secondary adrenal carcinomas, this procedure seems also to ensure a beneficial therapeutic approach for the treatment of isolated adrenal metastases $(78,79,82,83$, $85-87)$. In certain patients, who present no contraindications, laparoscopic adrenalectomy could be preformed safely with a complete absence of local recurrences $(78,79,82,83,85$ 87). Laparoscopic adrenalectomy may prove very useful in special cases of isolated adrenal metastases, but larger studies are needed.

Kim et al. from the Memorial Sloan-Kettering Cancer Center of New York have reviewed 17 cases of lung cancer metastasized to the adrenal glands. There were nine and eight synchronous and metachronous adrenal metastases; the median survival after the adrenalectomy was 14 months (81). In another large-scale study performed at Mayo Clinic fiftytwo patients with metastatic adrenal carcinomas were reviewed, of which eleven had lung cancer as primary malignancy. Forty per cent of all patients had a 2-year survival rate, and there was no significant difference in survival rates between patients with primary tumors in different locations (73).

Two studies $(50,51)$ have compared surgical with nonsurgical treatment of adrenal metastases in patients with lung cancer. Luketich and Burt have studied fourteen patients with NSCLC and a solitary adrenal metastasis. Eight of these patients underwent resection of both the lung cancer and the adrenal metastasis, whereas the remaining six patients received only chemotherapy. All patients treated medically were dead by 21 months, with a median survival of 8.5 months. In the surgical group the median survival was 31 months with three patients being alive at the time of publication at 3,21 and 61 months after operation, respectively. This outcome suggests that adrenalectomy in cases of complete control of the primary malignancy (51).

Higashiyama et al. have studied nine patients with adrenal carcinomas secondary to lung cancer, five of which underwent surgical resection of the adrenals, whereas the rest four received palliative therapy without adrenalectomy. Four and one of the adrenalectomized patients received chemotherapy and radiation, respectively, as an adjuvant therapy after the operation. Three and one of the patients treated with palliative therapy received chemotherapy and radiation, respectively. The results suggested that adrenalectomy could be effective for metastatic adrenal lesions from lung cancer in patients who have well controlled primary malignancy and long period between pulmonary resection and detection of adrenal metastases (not less than 7 months), adrenal metastasis is the initial metastasis, and no co-metastatic lesions are detected in other organs. Besides, in most cases adjuvant therapy in addition to adrenalectomy may be necessary, given the high incidence of metastases to other tissues (50).

Surgical treatment - Renal cancer as primary site. Regarding adrenal metastases from renal cancer, there have been 99 cases recorded $(54,55,58-60,61,64,68,70,72,73,76,77$, $81,82,85,87)$, and among them seventy-three cases have been reported in detail $(54,55,58-60,61,64,68,70,72,73$, $76,77,81,82,85,87)$. The remaining 26 cases were from two institutions and only summarized data have been presented $(73,81)$. Among the previously referred 73 patients, synchronous adrenal metastases occurred in 58 patients and the remaining 15 patients had metachronous metastases with time to detection ranging from 6 months to 19 years (median disease-free: 62 months). Among the 73 patients, thirty-two were alive at the time of the report with a mean survival of 36.6 months (range=7-122 months), with only four patients being 5-year survivors. Among the remaining 40 patients, 38 were dead at the time of the report with a mean survival of 27.7 months (range=1-172 months) and survival after adrenalectomy was not specified for two patients. Finally, 62 of the patients had an open adrenalectomy and only ten had laparoscopic one $(77,81,85,87)$.

Kim and associates have reviewed 11 metastatic adrenal carcinomas from malignancies of the kidneys, among which were 9 adenocarcinomas (renal cell carcinoma), one transitional cell carcinoma and one carcinoma of the collecting duct. There were six and five synchronous and metachronous adrenal metastases, respectively, and the median survival after adrenalectomy was 55 months (81). In a study conducted at Mayo Clinic, among the 52 patients reviewed, there were 15 cases of kidney malignancy 
Table III. Review of adrenal metastases treated surgically.

\begin{tabular}{|c|c|c|c|c|c|}
\hline First Author & Year & $\mathrm{n}$ & Primary site & Treatment of metastases & Survival after ADR \\
\hline O’Dea (55) & 1978 & 1 & Kidney & ADR & Alive: $\geq 7 \mathrm{mo}$ \\
\hline Foucar (56) & 1979 & 2 & Kidney & $\mathrm{ADR}$ & $\begin{array}{l}1 \text { Alive: } \geq 22 \mathrm{mo} \\
1 \text { Dead: } 14 \mathrm{mo}\end{array}$ \\
\hline Twomey (57) & 1982 & 2 & Lung & ADR \& $1 \mathrm{Rd}$ & Alive: $\geq 5,14 \mathrm{yr}$ \\
\hline Previte (6) & 1982 & 2 & Kidney & ADR & Alive: $\geq 20,24 \mathrm{mo}$ \\
\hline Neal (7) & 1982 & 2 & Kidney & ADR & 1 Alive: $\geq 3 \mathrm{yr}, 1$ not specified \\
\hline Campbe (118) & 1983 & 2 & Kidney & $\mathrm{ADR}$ & 1 Dead: 20 mo, 1 not specified \\
\hline Goldenberg (9) & 1983 & 1 & Kidney & ADR & Dead: 6 mo \\
\hline Fox $(58)$ & 1986 & 1 & Kidney & ADR & Alive: $\geq 18 \mathrm{mo}$ \\
\hline Selli (10) & 1987 & 3 & Kidney & ADR & Dead: 20 days, 6,9 mo \\
\hline Duggan (59) & 1987 & 1 & Kidney & ADR & Dead: 6 mo \\
\hline Tasca (60) & 1987 & 1 & Kidney & $\mathrm{ADR} \& \mathrm{Ch}$ & Dead: 1 mo \\
\hline Hasegawa (11) & 1988 & 2 & Kidney & ADR & Alive: $\geq 22,26 \mathrm{mo}$ \\
\hline Carey (61) & 1988 & 1 & Melanoma & $\mathrm{ADR} \& \mathrm{Ch}$ & Alive: $\geq 12 \mathrm{mo}$ \\
\hline Fujita (62) & 1988 & 1 & Rectum & ADR & Alive: $\geq 2 \mathrm{yr}$ \\
\hline Lemmers (63) & 1989 & 2 & Kidney & ADR & $\begin{array}{l}1 \text { Alive: } \geq 12 \mathrm{mo} \\
1 \text { Dead: } 14 \mathrm{mo}\end{array}$ \\
\hline Raviv (64) & 1990 & 3 & Lung & $\mathrm{ADR} \& 1 \mathrm{Ch}+\mathrm{Rd}$ & Dead: $24,25,35$ mo \\
\hline Reyes (65) & 1990 & 4 & Lung & $\begin{array}{l}\text { ADR \& } 2 \mathrm{Ch}, 1 \mathrm{Rd} \\
1 \mathrm{Ch}+\mathrm{Rd}\end{array}$ & $\begin{array}{l}2 \text { Alive: } \geq 5,24 \mathrm{mo} \\
2 \text { Dead: } 10,13 \mathrm{mo}\end{array}$ \\
\hline Winter (66) & 1990 & 8 & Kidney & $\mathrm{ADR}$ & $\begin{array}{c}3 \text { Alive: } \geq 39,52,58 \mathrm{mo} \\
\text { 5 Dead: } 18,20,28,31,35 \mathrm{mo}\end{array}$ \\
\hline Plawner (12) & 1991 & 7 & Kidney & ADR & $\begin{array}{c}2 \text { Alive: } \geq 32,60 \mathrm{mo} \\
\text { 5 Dead: } 7,9,58,80,172 \mathrm{mo}\end{array}$ \\
\hline Huisman (13) & 1991 & 2 & Kidney & ADR & $\begin{array}{l}1 \text { Alive: } \geq 48 \text { mo } \\
1 \text { Dead: } 29 \mathrm{mo}\end{array}$ \\
\hline Branum (1) & 1991 & 10 & Melanoma & ADR \& $2 \mathrm{Ch}$ & $\begin{array}{c}6 \text { Alive: } \geq 8,10,12,70,83,105 \mathrm{mo} \\
4 \text { Dead: } 3,8,9,112 \mathrm{mo}\end{array}$ \\
\hline Yu (24) & 1992 & 1 & Kidney & ADR & Dead: 7 mo \\
\hline Potepan (22) & 1992 & 1 & Osteogenic Osteosarcoma & ADR & not specified \\
\hline Dobnig (21) & 1992 & 1 & Non-Hodgkin Lymphoma & $\mathrm{ADR} \& \mathrm{Ch}, \mathrm{Rd}$ & Alive: $\geq 16$ mo \\
\hline Kirsch (67) & 1993 & 1 & Lung & $\mathrm{ADR} \& \mathrm{Ch}$ & Alive: $\geq 2 \mathrm{yr}$ \\
\hline Higashiyama (51) & 1994 & 5 & Lung & $\mathrm{ADR} \& 4 \mathrm{Ch}, 1 \mathrm{Rd}$ & $\begin{array}{l}2 \text { Alive: } \geq 24,40 \mathrm{mo} \\
3 \text { Dead: } 9,17,20 \mathrm{mo}\end{array}$ \\
\hline Sagalowsky (68) & 1994 & 21 & Kidney & ADR & $\begin{array}{c}4 \text { Alive: } \geq 9,32,114,122 \mathrm{mo} \\
17 \text { Dead: } 2,3,6,7,7,12,12,13,28, \\
28,33,35,40,45,48,55,86 \mathrm{mo}\end{array}$ \\
\hline Ayabe (69) & 1995 & 3 & Lung & $\mathrm{ADR} \& 2 \mathrm{Ch}$ & $\begin{array}{l}2 \text { Alive: } \geq 75,109 \text { mo } \\
1 \text { Dead: } 20 \mathrm{mo}\end{array}$ \\
\hline Barnes (70) & 1995 & 1 & Kindey & $\mathrm{ADR}$ & Alive: $\geq 7 \mathrm{y}$ \\
\hline Halachmi (71) & 1996 & 3 & Lung & ADR & not specified \\
\hline Dieckmann (72) & 1996 & 1 & Kidney & ADR & Alive: $\geq 9 \mathrm{mo}$ \\
\hline Lo (73) & 1996 & 52 & $\begin{array}{c}15 \text { Kidney, } 11 \text { Lung, } \\
7 \text { Colon, } 3 \text { Malignant } \\
\text { melanoma, } 3 \text { Stomach, } \\
2 \text { Urinary bladder, } 2 \text { Uterus, } \\
1 \text { Breast, } 1 \text { Prostate, } \\
1 \text { Gallbladder, } \\
1 \text { MFH, } 5 \text { Unknown }\end{array}$ & $\mathrm{ADR} \& 6 \mathrm{Ch}, 4 \mathrm{Rd}$ & $\begin{array}{l}22 \text { Alive: } 1 \mathrm{mo}-8.9 \mathrm{yr}^{*} \\
30 \text { Dead: } 1 \mathrm{mo}-8.6 \mathrm{yr}^{\dagger}\end{array}$ \\
\hline Suzuki (74) & 1997 & 1 & Lung & ADR & Dead: 8 mo \\
\hline Urschel (75) & 1997 & 1 & Lung & $\mathrm{ADR} \& \mathrm{Ch}$ & Alive: $\geq 9 \mathrm{yr}$ \\
\hline Sapienza (76) & 1997 & 1 & Kindey & ADR & Alive: $\geq 15$ mo \\
\hline Elashry (77) & 1997 & 2 & Kidney & ADR (Laparoscopic) & Alive: $\geq 11,16 \mathrm{mo}$ \\
\hline Bendinelli (78) & 1998 & 4 & Lung & ADR (Laparoscopic) \& Ch & $\begin{array}{l}1 \text { Alive: } \geq 8 \mathrm{mo} \\
3 \text { Dead: } 9,10,18 \mathrm{mo}\end{array}$ \\
\hline Linos (79) & 1998 & 1 & Lung & ADR (Laparoscopic) & Alive: $\geq 1 \mathrm{yr}$ \\
\hline Porte $(80)$ & 1998 & 11 & Lung & ADR & $\begin{array}{c}3 \text { Alive: } \geq 6,10,66 \mathrm{mo} \\
8 \text { Dead: } 4,4,6,6,8,13,14,24 \mathrm{mo}\end{array}$ \\
\hline
\end{tabular}


Table III. Continued

\begin{tabular}{|c|c|c|c|c|c|}
\hline First Author & Year & $\mathrm{n}$ & Primary site & Treatment of metastases & Survival after ADR \\
\hline $\operatorname{Kim}(81)$ & 1998 & 37 & $\begin{array}{c}17 \text { Lung, } 11 \text { Kidney, } \\
5 \text { Colon \& Rectum, } \\
1 \text { Esophagus, } 1 \text { Mediastinum, } \\
1 \text { Melanoma, } 1 \text { Unknown }\end{array}$ & $\mathrm{ADR} \& 5 \mathrm{Ch}, 5 \mathrm{Rd}$ & median: $21 \mathrm{mo}$ \\
\hline Heniford (82) & 1999 & 10 & $\begin{array}{c}4 \text { Kidney, } 2 \text { Lung, } \\
2 \text { Colon, } 1 \text { Adrenal, } \\
1 \text { Melanoma }\end{array}$ & ADR (9 Laparoscopic) & $\begin{array}{l}9 \text { Alive: } \geq 0.5-19 \mathrm{mo} \\
\text { (mean: } 8.3 \mathrm{mo} \text { ) } \\
1 \text { Dead: } 4.5 \mathrm{mo}\end{array}$ \\
\hline Tsuji (83) & 1999 & 1 & Lung & ADR (Laparoscopic) & Alive: $\geq 18 \mathrm{mo}$ \\
\hline De Perrot (84) & 1999 & 1 & Lung & $\mathrm{ADR} \& \mathrm{Rd}$ & Alive: $\geq 60 \mathrm{mo}$ \\
\hline Valeri (85) & 2001 & 6 & 5 Lung, 1 Kidney & ADR (Laparoscopic) & $\begin{array}{l}3 \text { Alive: } \geq 3,5,16 \mathrm{mo} \\
3 \text { Dead: } 18,36,36 \mathrm{mo}\end{array}$ \\
\hline Chen (86) & 2002 & 1 & Lung & ADR (Laparoscopic) & Dead: $10 \mathrm{mo}$ \\
\hline Kabebew (87) & 2002 & 13 & $\begin{array}{c}6 \text { Lung, } 3 \text { Kidney, } \\
2 \text { Lymphoma, } 1 \text { Melanoma, } \\
1 \text { Colon }\end{array}$ & ADR (Laparoscopic) & Mean: 3.3 yr (1-7 yr) \\
\hline Einat (88) & 2002 & 1 & Ovary & ADR (Laparoscopic) & Alive: $\geq 24$ mo \\
\hline Lam (89) & 2002 & 21 & $\begin{array}{l}1 \text { Rectum, the rest } \\
\text { not specified }\end{array}$ & ADR & $\begin{array}{l}1 \text { Alive: } \geq 72 \text { mo } \\
\text { The rest not specified }\end{array}$ \\
\hline Patlas (90) & 2004 & 1 & Ovarian & Decline treatment & \\
\hline Gerber (91) & 2004 & 14 & Lung & ADR (Laparoscopic) & Alive: $\geq 24$ mo \\
\hline Marcier (92) & 2005 & 23 & Lung & ADR & Alive: $\geq 6$ mo \\
\hline Tsalis (93) & 2005 & 1 & Hepatocellular & ADR & Alive: $\geq 6 \mathrm{mo}$ \\
\hline Miyoshi (94) & 2005 & 1 & Lung & ADR & Alive: $\geq 18 \mathrm{mo}$ \\
\hline Shoji (95) & 2006 & 1 & Colorectal & ADR & Alive: $\geq 12$ mo \\
\hline Utsumi (96) & 2008 & 1 & Renal & $\mathrm{ADR}$ & Alive: $\geq 12$ mo \\
\hline Fumagali (97) & 2010 & 1 & Esophagogastric junction & ADR & Alive: $\geq 6$ mo \\
\hline Liu (98) & 2010 & 1 & Breast & ADR & Alive: $\geq 36$ mo \\
\hline Raz (99) & 2011 & 21 & Lung & ADR & Alive: $\geq 12$ mo \\
\hline Thrumurthy (100) & 2011 & 1 & Colorectal & $\mathrm{ADR} \& 2 \mathrm{Ch}$ & Alive: $\geq 24$ mo \\
\hline Washino (101) & 2012 & 1 & Bladder & ADR \& 3Ch & Alive: $\geq 36$ mo \\
\hline Zakaria (102) & 2013 & 1 & Bladder & ADR & Alive: $\geq 36$ mo \\
\hline Solaini (103) & 2013 & 1 & Seminoma & ADR & Alive: $\geq 18 \mathrm{mo}$ \\
\hline Mouka (104) & 2016 & 1 & Endometrial & $\mathrm{ADR} \& \mathrm{Ch}$ & Alive: $\geq 18$ mo \\
\hline Yuan (105) & 2017 & 34 & Lung & $\begin{array}{c}\text { ADR (Laparoscopic) } \\
\text { \& ADR }\end{array}$ & Median $\geq 45$ mo \\
\hline Eddaoualline (106) & 2018 & 1 & Ewing Sarcoma & ADR \& $12 \mathrm{Ch}$ & Alive: $\geq 36$ mo \\
\hline Hanato (107) & 2018 & 25 & $\begin{array}{l}\text { Lung, Kidney, Ovary, } \\
\text { Soft Tissue, six Others }\end{array}$ & $\begin{array}{c}\text { ADR (Laparoscopic) } \\
\text { \& ADR }\end{array}$ & Median $\geq 14$ mo \\
\hline Nugroho (108) & 2018 & 1 & $\begin{array}{l}\text { Hepatocellular carcinoma- } \\
\text { cholangiocarcinoma }\end{array}$ & ADR & Alive: $\geq 12 \mathrm{mo}$ \\
\hline Total & & 399 & $\begin{array}{l}99 \text { Kidney, } 176 \text { Lung, } \\
17 \text { Melanoma, } 17 \text { Colon } \\
\text { \& Rectum, } 3 \text { Stomach, } \\
3 \text { Urinary bladder, } 3 \\
\text { Malignant Lymphoma, } \\
2 \text { Uterus, 1 Esophagus, } 1 \\
\text { Mediastinum, 1 Ovary, } 1 \\
\text { Kidney, } 1 \text { Soft Tissue, } 2 \\
\text { Breast, 1 Prostate, } 1 \\
\text { Gallbladder, 1 MFH, } 1 \\
\text { Osteogenic Osteosarcoma, } \\
1 \text { Hepatocellular, 1 Esophago- } \\
\text { gastric junction, 1 cholangio- } \\
\text { carcinoma, 1 Cervix, } 2 \text { Ovary, } \\
1 \text { Adrenal, 1 Ewing Sarcoma, } \\
1 \text { Hepatocellular, 1 Seminoma } \\
2 \text { Bladder, } 3 \text { Colorectal, 26 } \\
\text { not specified, } 6 \text { Unknown }\end{array}$ & & \\
\hline
\end{tabular}

*Median: 24 mo; ${ }^{\dagger}$ Median: 13 mo. ADR: Adrenalectomy; Ch: chemotherapy; Rd: radiation; mo: months; yr: years; MFH: malignant fibrous histiocytoma. 
metastasized to the adrenals and $40 \%$ of all patients had a 2year survival (73).

\section{Surgical treatment - Other primary sites}

Apart from malignancies of the lung and kidney among other primary sites (88-108), eleven studies with 79 cases of other primary cancers metastatic to the adrenal glands which were treated with adrenalectomy were identified (Table III). Two of these studies that have been conducted at the Memorial Sloan-Kettering Cancer Center of New York (81) and Mayo Clinic (73), respectively, summarized the data. The remaining nine studies $(1,21,22,61,62,82$, 85-89) contained sufficient data but number of cases was small or had insufficient data. The larger of these two studies, conducted by Branum and associates, have compared surgical with non-surgical treatment of 24 patients with melanoma metastatic to the adrenals. Fourteen patients were treated with chemotherapy (Table II), whereas the remaining ten patients underwent adrenalectomy. All 10 patients had unilateral metastasis to the adrenal gland. At the time of publication, six of the operated patients remained alive for $8,10,12,70,83$ and 105 months, respectively, and four were dead 3, 8, 9 and 112 months after the adrenalectomy, respectively. Among the 14 patients who received chemotherapy, 3 were alive and 11 dead, as described above. Survival analysis revealed a significant survival advantage in the surgically treated group ( $p=0.0095)$, supporting that patients with isolated adrenal metastases may benefit from an aggressive treatment of the adrenal disease (1).

\section{Conclusion}

As a general principle, resection of a single site metastatic disease should be attempted, considering that the operation is feasible and without major morbidity and if the primary malignancy can be (or was) also surgically treated in a curative intent $(112,113)$. In the case of metastatic adrenal carcinomas, the main problem is to establish preoperatively that the metastasis is truly isolated (114). Once this has been achieved, adrenalectomy seems to be the procedure of choice, as it has the potential to offer prolonged survival.

\section{Conflicts of Interest}

The Authors declare no conflicts of interest regarding this study.

\section{Authors' Contributions}

ES and ID performed the literature search and wrote the paper; AI and DC screened the retrieved articles and performed data extraction; DIA and MS created the tables; DA critically revised the final manuscript.

\section{References}

1 Branum GD, Epstein RE, Leight GS and Seigler HF: The role of resection in the management of melanoma to the adrenal gland. Surgery 109: 127-131, 1991. PMID: 1992544.

2 Seidenwurm DJ, Elmer EB, Kaplan LM, Williams EK, Morris DG and Hoffman AR: Metastases to the adrenal glands and the development of Addison's disease. Cancer 54: 552-557, 1984. PMID: 6733685.

3 Cedermark BJ, Blumenson LE, Pickren JW and Elias EG: The significance of metastases to the adrenal gland from carcinoma of the stomach and esophagus. Surg Gynecol Obstet 145: 4148, 1977. PMID: 877823.

4 Cedermark BJ, Blumenson LE, Pickren JW, Holyoke DE and Elias EG: The significance of metastases to the adrenal glands in adenocarcinoma of the colon and rectum. Surg Gynecol Obstet 144: 537-546, 1977. PMID: 847609.

5 Tsukamoto E, Itoh K, Kanegae K, Kobayashi S, Koyanagi T and Tamaki N: Accumulation of Iodine-131-Iodocholesterol in renal cell carcinoma adrenal metastases. J Nucl Med 39: 656658, 1998. PMID: 9544676.

6 Previte SR, Willscher MK and Burke CR: Renal cell carcinoma with solitary contralateral metastasis: experience with 2 cases. J Urol 128: 132-134, 1982. PMID: 7109047.

7 Neal PM, Leach GE, Kaswick JA and Lieber MM: Renal cell carcinoma: Recognition and treatment of synchronous solitary contralateral adrenal metastasis. J Urol 128: 135-136, 1982. PMID: 7109048.

8 Campbell CM, Middleton RG and Rigby OF: Adrenal metastasis in renal cell carcinoma. Urology 21: 403-405, 1983. PMID: 6836834.

9 Goldenberg SL, Wright JE and McLoughlin MG: Metastatic renal cell carcinoma: Unusual cause of Addison disease. Urology 22: 408-409, 1983. PMID: 6636399.

10 Selli C, Carini M, Barbanti G, Barbagli G and Turini D: Simultaneous bilateral adrenal involvement by renal cell carcinoma: experience with 3 cases. J Urol 137: 480-482, 1987. PMID: 3820378.

11 Hasegawa J, Okumura S, Abe H, Kanamori S, Yoshida K and Akimoto M: Renal cell carcinoma with solitary contralateral adrenal metastasis. Urology 32: 52-53, 1988. PMID: 3388659.

12 Plawner J: Results of surgical treatment of kidney cancer with solitary metastasis to contralateral adrenal. Urology 37: 233236, 1991. PMID: 2000680.

13 Huisman TK and Sands JP: Renal cell carcinoma with solitary metachronous contralateral adrenal metastasis: Experience with 2 cases and review of the literature. Urology 38: 364-368, 1991. PMID: 1755149.

14 Saitoh H: Distant metastasis of renal adenocarcinoma. Cancer 48: 1487-1491, 1981. PMID: 7272969.

15 Luciani L, Scappini P, Pusiol T and Piscioli F: Aspiration cytology of simultaneous bilateral adrenal metastases from renal cell carcinoma. A case report and review of the literature. J Urol 134: 315-318, 1985. PMID: 3894696.

16 Otabe S, Muto S, Asano Y, Sato K, Ohtani M, Kawamoto C, Ido $\mathrm{K}$ and Kimura $\mathrm{K}$ : Hyperreninemic hypoaldosteronism due to hepatocellular carcinoma metastatic to the adrenal gland. Clin Nephrol 35: 66-71, 1991. PMID: 1850333.

17 Okuda K, Arakawa M, Kubo Y, Sakata K, Kage M, Iwamoto S, Takeda S, Sonoda K and Sanefuji H: Right-sided pedunculated 
hepatocellular carcinoma: A form of adrenal metastasis. Hepatology 27: 81-85, 1998. PMID: 9425921. DOI: 10.1002/ hep.510270114

18 Kennedy RL, Ball RY, Dixon AK and ApSimon AT: Metastatic transitional cell carcinoma of the bladder causing Addison's disease. J Urol 137: 986-988, 1987. PMID: 3573205.

19 Carey RW, Harris N and Kliman B: Addison's disease secondary to lymphomatous infiltration of the adrenal glands. Recovery of adrenocortical function after chemotherapy. Cancer 59: 1087-1090, 1987. PMID: 3815281.

20 Feinmann C, Gillett R and Irving MH: Hodgkin's disease presenting with hypoadrenalism. Br Med J 2: 455-456, 1976. PMID: 953605. DOI: $10.1136 / \mathrm{bmj} .2 .6033 .455$

21 Dobnig H, Silly H, Ohlinger W, Neubauer M, Leb G and Krejs GJ: Successful treatment of primary adrenal insufficiency due to malignant non-Hodgkin's lymphoma. Clin Investig 70: 938941, 1992. PMID: 1450618.

22 Potepan P, Danesini GM, Spagnoli I, Laffranchi A, Giovannardi $\mathrm{G}$, Turrini E and Guzzon A: Adrenal gland metastasis in osteogenic osteosarcoma. A radiological case report. Tumori 78: 417-420, 1992. PMID: 1297240.

23 Linos DA: Management approaches to adrenal incidentalomas (adrenalomas). A view from Athens, Greece. Endocrin Metab Clin North Am 29: 141-157, 2000. PMID: 10732269.

24 Yu CC, Huang JK, Tzeng WS, Wu JD, Lee YH and Jiaan BP: Simultaneous bilateral adrenal metastases from renal cell carcinoma. Eur Urol 22: 335-338, 1992. PMID: 1490512.

25 Vieweg WV, Reitz RE and Weinstein RL: Addison's disease secondary to metastatic carcinoma: an example of adrenocortical and adrenomedullary insufficiency. Cancer 31: 1240-1243, 1973. PMID: 4350184.

26 Linos DA: Adrenaloma: A better term than incidentaloma. Surgery 105: 456, 1989. PMID: 2922684.

27 Linos DA and Stylopoulos N: How accurate is computed tomography in predicting the real size of adrenal tumors? Arch Surg 132: 740-743, 1997. PMID: 9230858.

28 Allard P, Yankaskas BC, Fletcher RH, Parker LA and Halvorsen RA Jr: Sensitivity and specificity of computed tomography for the detection of adrenal metastatic lesions among 91 autopsied lung cancer patients. Cancer 66: 457-462, 1990. PMID: 2163745.

29 Antonelli A, Cozzoli A, Simeone C, Zani D, Zanotelli T, Portesi E, Cosciani, and Cunico S: Surgical treatment of adrenal metastasis from renal cell carcinoma: a single-centre experience of 45 patients. BJU International 97: 505-508, 2006. PMID: 16469016. DOI: 10.1111/j.1464-410X.2006.05934.x

30 Porte HL, Ernst OJ, Delebecq T, Métois D, Lemaitre LG and Wurtz AJ: Is computed tomography guided biopsy still necessary for the diagnosis of adrenal masses in patients with resectable non-small-cell lung cancer? Eur J Cardiothorac Surg 15: 597-601, 1999. PMID: 10386403. DOI: 10.1016/s10107940(99)00047-0

31 Sandler MA, Pearlberg JL, Madrazo BL, Gitschlag KF and Gross SC: Computed tomographic evaluation of the adrenal gland in the preoperative assessment of bronchogenic carcinoma. Radiology 145: 733-736, 1982. PMID: 7146405. DOI: $10.1148 /$ radiology.145.3.7146405

32 Oliver TW, Bernardino ME, Miller JI, Mansour K, Greene D and Davis WA: Isolated adrenal masses in nonsmall-cell bronchogenic carcinoma. Radiology 153: 217-218, 1984. PMID: 6473783. DOI:10.1148/radiology.153.1.6473783
33 Burt M, Heelan RT, Coit D, McCormack PM, Bains MS, Martini N, Rusch V and Ginsberg RJ: Prospective evaluation of unilateral adrenal masses in patients with operable nonsmall-cell lung cancer. Impact of magnetic resonance imaging. J Thorac Cardiovasc Surg 107: 584-589, 1994. PMID: 8302078.

34 Goerg C, Schwerk WB, Wolf M and Havemann K: Adrenal masses in lung cancer: sonographic diagnosis and follow-up. Eur J Cancer 28A: 1400-1403, 1992. PMID: 1515257.

35 Zornoza $\mathrm{J}$ and Bernardino ME: Bilateral adrenal metastasis: "Head light" sign. Urology 15: 91-92, 1980. PMID: 7352357.

36 Loccoco F, Patricelli G, Galeone C and Rapicetta C: Surgery of isolated adrenal metastasis from non small cells lung cancer: the role of preoperative PET/CT scan. Interact Cardiovasc Thorac Surg 24: 4, 2017. PMID: 28052982. DOI: 10.1093/ icvts/ivw386

37 Quraishi MA, Costanzi JJ and Balachandran S: Iodocholesterol adrenal scanning for the detection of adrenal metastases in lung cancer and its clinical significance. Cancer 48: 714-716, 1981. PMID: 7248897.

38 Leitha T, Meghdadi S, Studnicka M, Wolzt M, Marosi C, Angelberger P, Neumann M, Schlick W, Kletter K and Dudczak $\mathrm{R}$ : The role of Iodine-123-Tyr-3-Octreotide scintigraphy in the staging of small-cell lung cancer. J Nucl Med 34: 1397-1402, 1993. PMID: 8394882.

39 Boland GW, Goldberg MA, Lee MJ, Mayo-Smith WW, Dixon $\mathrm{J}, \mathrm{McNicholas} \mathrm{MM}$ and Mueller PR: Indeterminate adrenal mass in patients with cancer: evaluation at PET with 2-[F-18]fluoro-2-deoxy-D-glucose. Radiology 194: 131-134, 1995. PMID: 7997539. DOI: 10.1148/radiology.194.1.7997539

40 Erasmus JJ, Patz EF, McAdams HP, Murray JG, Herndon J, Coleman RE and Goodman PC: Evaluation of adrenal masses with bronchogenic carcinoma using ${ }^{18} \mathrm{~F}$-fluorodeoxyglucose positron emission tomography. AJR 168: 1357-1360, 1997. PMID: 9129444. DOI: 10.2214/ajr.168.5.9129444

41 Harrison J, Ali A, Bononi P and Prinz R: The role of positron emission tomography in selecting patients with metastatic cancer for adrenalectomy. Am Surg 66: 432-436, 2000. PMID: 10824742.

42 Berkman WA, Bernardino ME, Sewell CW, Price RB and Sones PJ Jr: The computed tomography-guided adrenal biopsy. An alternative to surgery in adrenal mass diagnosis. Cancer 53: 2098-2103, 1984. PMID: 6704899.

43 Pagani JJ: Non-small cell lung carcinoma adrenal metastases. Computed tomography and percutaneous needle biopsy in their diagnosis. Cancer 53: 1058-1060, 1984. PMID: 6692299.

44 Ettinghausen SE and BurtME: Prospective evaluation of unilateral adrenal masses in patients with operable non-smallcell lung cancer. J Clin Oncol 9: 1462-1466, 1991. PMID: 1649268. DOI: $10.1200 /$ JCO.1991.9.8.1462

45 De Agustin P, Lopez-Rios F, Alberti N and Perez-Barrios A: Fine-needle aspiration biopsy of the adrenal glands: a ten-year experience. Diagn Cytopathol 21: 92-97, 1999. PMID: 10425045.

46 Chapman GS, Kumar D, Redmond J 3rd, Munderloh SH and Gandara DR: Upper abdominal computerized tomography scanning in staging non-small cell lung carcinoma. Cancer 54: 1541-1543, 1984. PMID: 6478395.

47 Harper PG, Houang M, Spiro SG, Geddes D, Hodson M and Souhami RL: Computerized axial tomography in the pretreatment assessment of small-cell carcinoma of the bronchus. Cancer 47: 1775-1780, 1981. PMID: 6261927. 
48 Nielsen ME, Heaston DK, Dunnick NR and Korobnik M: Preoperative CT evaluation of adrenal glands in non-small bronchogenic carcinoma. AJR 139: 317-320,1982. PMID: 6979884. DOI: 10.2214/ajr.139.2.317

49 Paivansalo M, Lahde S, Merikanto $\mathrm{J}$ and Kallionen M: Computed tomography in primary and secondary adrenal tumours. Acta Radiologica 29: 519-522, 1988. PMID: 3166873 .

50 Whittlesey D: Prospective computed tomographic scanning in the staging of bronchogenic cancer. J Thorac Cardiovasc Surg 95: 876-882, 1988. PMID: 3361935.

51 Higashiyama M, Doi O, Kodama K, Yokouchi H, Imaoka S and Koyama H: Surgical treatment of adrenal metastasis following pulmonary. Int Surg 79: 124-129, 1994. PMID: 7523325.

52 Luketich JD and Burt ME: Does resection of adrenal metastases from non-small cell lung cancer improve survival? Ann Thorac Surg 62: 1614-1616, 1996. PMID: 8957360.

53 Soffen EM, Solin LJ, Rubenstein JH and Hanks GE: Palliative radiotherapy for symptomatic adrenal metastases. Cancer 65: 1318-1320, 1990. PMID: 2155051.

54 Yuan BY, Hu Y, Zhang L Chen YH, Dong YY and Zeng ZC: Radiotherapy for adrenal gland metastases from hepatocellular carcinoma. Clin Trans Oncol 19: 1154-1160, 2017. PMID: 28357632. DOI: $10.1007 / \mathrm{s} 12094-017-1654-\mathrm{X}$

55 O'Dea MJ, Zincke H, Utz DC and Bernatz PE: The treatment of renal cell carcinoma with solitary matastasis. J Urol 120: 540-542, 1978. PMID: 712892.

56 Foucar E and Dehner LP: Renal cell carcinoma occurring with contralateral adrenal metastasis. Arch Surg 114: 959-963, 1979. PMID: 464812.

57 Twomey P, Montgomery C and Clark O: Successful treatment of adrenal metastases from large-cell carcinoma of the lung. JAMA 248: 581-583, 1982. PMID: 6285013.

58 Fox M, Grant JB and Grainger RG: Bilateral adrenal metastases from renal carcinoma treated surgically with prolonged survival. Br J Urol 58: 561-563, 1986. PMID: 3779362.

59 Duggan MA, Forestell CF and Hanley DA: Adrenal metastases of renal-cell carcinoma 19 years after nephrectomy. Fine needle aspiration cytology of a case. Acta Cytologica 31: 512-516, 1987. PMID: 3604547.

60 Tasca A, Calabro A, Aragona F and Ranieri A: Bilateral adrenal metastasis from renal cell carcinoma. Acta Urol Belg 55: 369372, 1987. PMID: 3661318.

61 Carey RW and Kunz VS: Leukocytosis due to adrenal metastases from malignant melanoma: reversal after bilateral adrenalectomy with long-term survival. Am J Hematol 27: 228229, 1998. PMID: 3348209.

62 Fujita K, Kameyama S and Kawamura M: Surgically removed adrenal metastasis from cancer of the rectum. Dis Colon Rectum 31: 141-143, 1988. PMID: 3338346.

63 Lemmers $M$, Ward $K$, Hatch $T$ and Stenzel P: Renal adenocarcinoma with solitary metastasis to the contralateral adrenal gland: Report of 2 cases and review of the literature. J Urol 141: 1177-1180, 1989. PMID: 2651718.

64 Raviv G, Klein E, Yellin A, Schneebaum S and Ben-Ari G: Surgical treatment of solitary adrenal metastases from lung carcinoma. J Surg Oncol 43: 123-124, 1990. PMID: 1689433.

65 Reyes L, Parvez Z, Nemoto T, Regal AM and Takita H: Adrenalectomy for adrenal metastasis from lung carcinoma. J Surg Oncol 44: 32-34, 1990. PMID: 2342373.
66 Winter P, Miersch WD, Vogel J and Jaeger N: On the necessity of adrenal extirpation combined with radical nephrectomy. $\mathrm{J}$ Urol 144: 842-844, 1990. PMID: 2398555.

67 Kirsch AJ. Oz MC, Stoopler M, Ginsburg M and Steinglass K: Operative management of adrenal metastases from lung carcinoma. Urology 42: 716-719, 1993. PMID: 8256407.

68 Sagalowsky AI, Kadesky KT, Ewalt DM and Kennedy TJ: Factors influencing adrenal metastasis in renal cell carcinoma. J Urol 151: 1181-1184, 1994. PMID: 8158755.

69 Ayabe H, Tsuji H, Hara S, Tagawa Y, Kawahara K and Tomita M: Surgical management of adrenal metastasis from bronchogenic carcinoma. J Surg Oncol 58: 149-154, 1995. PMID: 7898109.

70 Barnes RD, Abratt RP, Cant PJ and Dent DM: Synchronous contralateral adrenal metastasis from renal cell carcinoma: a 7 year survival following resection. Aust NZ J Surg 65: 540-541, 1995. PMID: 7611979.

71 Halachmi S, Best LA, Moskovitz B, Madjar S and Nativ O: Transthoracal approach for the removal of adrenal tumors. Eur Urol 30: 480-483, 1996. PMID: 8977071.

72 Dieckmann K-P, Wullbrand A and Krolzig G: Contralateral adrenal metastasis in renal cell cancer. Scand J Urol Nephro 30: 139-143, 1996. PMID: 8738061.

73 Lo CY, Van Heerden JA, Soreide JA, Grant CS, Thompson GB, Lloyd RV and Harmsen WS: Adrenalectomy for metastatic disease to the adrenal glands. Br J Surg 83: 528-531, 1996. PMID: 8665251.

74 Suzuki K, Ushiyama S, Mugiya S, Kageyama S, Saisu K and Fujita K: Hazards of laparoscopic adrenalectomy in patients with adrenal malignancy. J Urol 158: 2227, 1997. PMID: 9366350.

75 Urschel JD, Finley RK and Takita H: Long-term survival after bilateral adrenalectomy for metastatic lung cancer. Chest 112: 848-850, 1997. PMID: 9315827. DOI: 10.1378/chest.112.3.848

76 Sapienza P, Stipa F, Lucandri G, Baratti L, Delfino M and Mingazzini PL: Renal carcinoma with a solitary synchronous contralateral adrenal metastasis: a case report. Anticancer Res 17: 743-748, 1997. PMID: 9066613.

77 Elashry OM, Clayman RV, Soble JJ and McDougal EM: Laparoscopic adrenalectomy for solitary metachronous contralateral adrenal metastasis from renal cell carcinoma. J Urol 157: 1217-1222, 1997. PMID: 9120905.

78 Bendinelli C, Lucchi M, Buccianti P, Iacconi P, Angeletti CA and Miccoli P: Adrenal masses in non-small cell lung carcinoma patients: is there any role for laparoscopic procedures? J Laparoendosc Adv Surg Tech 8: 119-124, 1998. PMID: 9681423. DOI: 10.1089/lap.1998.8.119

79 Linos DA, Avlonotis VS and Iliadis K: Laparoscopic resection of solitary adrenal metastasis from lung carcinoma: a case report. J Soc Laparoendosc Surg 2: 291-293, 1998. PMID: 9876758.

80 Porte HL, Roumilhac D, Graziana JP, Eraldi L, Cordonier C, Puech P, and Wurtz AJ: Adrenalectomy for a solitary adrenal metastasis from lung cancer. Ann Thorac Surg 65: 331-335, 1998. PMID: 9485224.

81 Kim SH, Brennan MF, Russo P, Burt ME and Coit DG: The role of surgery in the treatment of clinically isolated adrenal metastasis. Cancer 82: 389-394, 1998. PMID: 9445197.

82 Heniford BT, Arca MJ, Walsh RM and Gill IS: Laparoscopic adrenalectomy for cancer. Semin Surg Oncol 16: 293-306, 1999. PMID: 10332775. 
83 Tsuji Y, Yashuku M, Haryu T, Watanabe Y, Ataka K and Okada M: Laparoscopic adrenalectomy for solitary metachronous adrenal metastasis from lung cancer: report of a case. Surg Today 29: 1277-1279, 1999. PMID: 10639712. DOI: 10.1007/ BF02482223

84 De Perrot M, Licker M, Robert JH and Spiliopoulos A: Long term survival after surgical resections of bronchogenic carcinoma and adrenal metastasis. Ann Thorac Surg 68: 10841085, 1999. PMID: 10510021.

85 Valeri A, Borrelli A, Presenti L, Lucchese M, Venneri F, Mannelli M, Regio S and Borrelli D: Adrenal masses in neoplastic patients. The role of laparoscopic procedure. Surg Endosc 15: 90-93, 2001. PMID: 11178771.

86 Chen B, Zhou M, Cappelli MC and Wolf JS: Port site, retroperitoneal and intra-abdominal recurrence after laparoscopic adrenalectomy for apparently isolated metastasis. J Urol 168: 2528-2529, 2002. PMID: 12441957. DOI: 10.1097/ 01.ju.0000036520.14371.52

87 Kebebew E, Siperstein AE, Clark OH and Duh QY: Results of laparoscopic adrenalectomy for suspected and unsuspected malignant adrenal neoplasms. Arch Surg 137: 948-953, 2002. PMID: 12146996.

88 Einat S, Amir S, Silvia M and Moshe I: Successful laparoscopic removal of a solitary adrenal metastasis from ovarian carcinoma: a case report. Gynecol Oncol 85: 201-203, 2002. PMID: 11925146. DOI: 10.1006/gyno.2001.6547

89 Lam KY and Lo CY: Metastatic tumours of the adrenal glands: a 30-year experience in a teaching hospital. Clin Endocrin 56: 95-101, 2002. PMID: 11849252.

90 Patlas M, O' Malley M and Chapman W: Adrenal metastasis form ovarian carcinoma. AJR Am J Roentgenol 183: 1711-1712, 2004. PMID: 15547215. DOI: 10.2214/ajr.183.6.01831711

91 Gerber E, Dinlnec C and Wagner J: Laparoscopic adrenalectomy for isolated adrenal metastasis. JSLS 8: 314-319, 2004. PMID: 15554272.

92 Mercier O, Fadel E, de Perrot M Mussot S, Stella F, Chapelier A and Dartevelle P: Surgical treatment of solitary adrenal metastasis from non small cell cancer. J Thorac Cardiovasc Surg 130: 136140, 2005. PMID: 15999053. DOI: 10.1016/j.jtcvs.2004.09.020

93 Tsalis K, Zacharakis E, Sapidis N Lambrou I, Zacharakis E and Betsis D: Adrenal metastasis as first presentation of hepatocellular carcinoma. World J Surg Oncol 25: 43-50, 2005. PMID: 16042808. DOI: 10.1186/1477-7819-3-50

94 Miyoshi T, Otsuka F, Suzuki J Inagaki K, Kano Y, Ogura T, Kiura K, Saika T and Makino H: Abrupt enlargement of adrenal incidentaloma: a case of isolated adrenal metastasis. Endocr J 52: 785-788, 2005. PMID: 16410674.

95 Shoji Y, Dohke M, Masuda T Nakamura F, Yano T, Niizeki H, Kashimura $\mathrm{N}$ and Matsunami O: Solitary adrenal metastasis in a patient with sigmoid colon cancer; report of a case. Int $\mathbf{J}$ Gastrointest Cancer 37: 120-123, 2006. PMID: 18175226. DOI: 10.1007/s12029-007-9001-z

96 Utsumi T, Suzuki H, Nakamura K Kim W, Kamijima S, Awa Y, Araki K, Nihei N, Naya Y and Ichikawa T: Renal cell carcinoma with a huge solitary metastasis to the contralateral adrenal gland: a case report. Int J Urol 15: 1077-1079, 2008. PMID: 19120516. DOI: 10.1111/j.1442-2042.2008.02182.x

97 Fumagalli U, de Carli S, de Pascale S Rimassa L, Bignardi M and Rosati R: Adrenal metastases from adenocarcinoma of the esophagogastric junction: adrenalectomy and long-term survival. Updates Surg 62: 63-67, 2010. PMID: 20845103. DOI: $10.1007 / \mathrm{s} 13304-010-0012-0$

98 Liu XJ, Shen P, Wang XF Sun K and Sun FF: Solitary adrenal metastasis from invasive ductal breast cancer: an uncommon finding. World J Surg Oncol 8: 7, 2010. PMID: 20105336. DOI: 10.1186/1477-7819-8-7

99 Raz DJ, Lanuti M, Gaissert HC Wright CD, Mathisen DJ and Wain JC: Outcomes of patients with isolated adrenal metastasis from non-small cell lung carcinoma. Ann Thorac Surg 92: 1788-1792, 2011. PMID: 21944257. DOI: 10.1016/j.athoracsur. 2011.05.116

100 Thrumurthy SG, Jadav AM, Pitt M Dobson M, Hearn A, Scott NA and Susnerwala SS: Metachronous bilateral adrenal metastases following curative treatment for colorectal carcinoma. Send to Ann R Coll Surg Engl 93: e96-98, 2011. PMID: 21929898. DOI: 10.1308/147870811X591134

101 Washino S, Hirai M, Matsuzaki A and Kobayashi Y: Long-term survival after adrenalectomy for asynchronous metastasis of bladder cancer to the bilateral adrenal glands. Case Rep Urol 2012: 425230, 2012. PMID: 23213615. DOI: 10.1155/ 2012/425230

102 Zakaria B, Pierre-Etienne T, Véronique D, Vincent M, Walid M and Hervé B : A case of adrenal metastasis in seminoma. Case Rep Urol 2013: 495743, 2013. PMID: 24027650. DOI: $10.1155 / 2013 / 495743$

103 Solaini L, Arru L, Merigo G, Tomasoni M, Gheza F and Tiberio GA: Advanced sealing and dissecting devices in laparoscopic adrenal surgery. JSLS 17: 622-626, 2013. PMID: 24398206. DOI: $10.4293 / 108680813$ X13693422520350

104 Mouka V, Tsili AC, Messinis T, Papoudou-Bai A, Kamina S and Argyropoulou MI: Solitary adrenal metastasis from early-stage dedifferentiated endometrial carcinoma: CT findings and review of the literature. J Obstet Gynaecol 36: 881-882, 2016. PMID: 27624653. DOI: $10.1080 / 01443615.2016 .1188275$

105 Yuan BY, Hu Y, Zhang L, Chen YH, Dong YY and Zeng ZC: Radiotherapy for adrenal gland metastases from hepatocellular carcinoma. Clin Transl Oncol 19: 1154-1160, 2017. PMID: 28357632. DOI: $10.1007 / \mathrm{s} 12094-017-1654-\mathrm{x}$

106 Eddaoualline H, Mazouz K, Rafiq B, El Mghari Tabib G, El Ansari N, Belbaraka R, El Omrani A and Khouchani M: Ewing sarcoma of the adrenal gland: a case report and review of the literature. J Med Case Rep 12: 69, 2018. PMID: 29544549. DOI: 10.1186/s13256-018-1601-7

107 Hatano K, Horii S, Nakai Y, Nakayama M, Kakimoto KI and Nishimura K: The outcomes of adrenalectomy for solitary adrenal metastasis: A 17-year single-center experience. Asia Pac J Clin Oncol 30: 2018. PMID: 30270570. DOI: 10.1111/ ajco.13078

108 Nugroho A, Lee KW, Lee KB, Kim HS, Kim H, Yi NJ and Suh KS: Adrenal metastasis in sequentially developed combined hepatocellular carcinoma-cholangiocarcinoma: A case report. Ann Hepatobiliary Pancreat Surg 22: 287-291, 2018. PMID: 30215052. DOI: 10.14701/ahbps.2018.22.3.287

109 Luketich JD, Martini N, Ginsberg RJ, Rigberg D and Burt ME: Successful treatment of solitary extracranial metastases from non-small cell lung cancer. Ann Thorac Surg 60: 1609-1611, 1995. PMID : 8787451. DOI: 10.1016/0003-4975(95)00760-1

110 Taira N, Kawabata T, Ichi T, Kushi K, Yohena T, Kawasaki H and Ishikawa $\mathrm{K}$ : Long-term survival after surgical treatment of metachronous bilateral adrenal metastases of non-small cell lung carcinoma. Am J Case Rep 15: 444-446, 2014. PMID: 25317919. DOI: 10.12659/AJCR.891027 
111 Yokosuka K, Kawashima T, Okada N, Wakabayashi T, Kawashima S, Kuroda T, Nishi Y, Tanabe M, Gotoh T, Shirai $\mathrm{K}$ and Matsuzawa $\mathrm{Y}$ : Impaired consciousness caused by a metastatic adrenal tumor of pulmonary adenocarcinoma. Intern Med 47: 109-112, 2008. PMID: 18195500.

112 Karolyi P: Do adrenal metastases from lung cancer develop by lymphogenous or hematogenous route? J Surg Oncol 43: 154156, 1990. PMID: 2314102.

113 Rosenberg SA: Principles of cancer management: Surgical oncology. In: De Vita VT, Hellman S, Rosenberg SA. Cancer: principles and practice of oncology. Philadelphia: LippincottRaven, pp. 304, 1997.
114 Porte H, Siat J, Guibert B, Lepimpec-Barthes F, Jancovici R, Bernard A, Foucart A and Wurtz A: Resection of adrenal metastases from non-small lung cancer: a multicenter study. Ann Thorac Surg 71: 981-985, 2001. PMID: 11269485.

Received April 8, 2019

Revised May 18, 2019

Accepted May 21, 2019 